\title{
The effect of drought and cropping system on the yield and yield components of maize (Zea mays L.)
}

\author{
Salifu Mahama \\ University of Debrecen Faculty of Agricultural and Food Sciences and Environmental Management, \\ Institute of Crop Sciences, Debrecen, Hungary \\ salifumahama@agr.unideb.hu
}

\section{SUMMARY}

\begin{abstract}
Different Cropping Systems have many advantages and ensure better crop growth and yielding. Its combination with other agronomic measures can ensure optimal crop density for maximum crop growth and photosynthesis efficiency. The aim of this study was to investigate the influence of different cropping systems on monoculture and biculture rotations [maize-wheat]. The study found that crop rotation does not have a significant effect on the grain nutrition quality, Leaf Area Index (LAI) and Normalized Difference Vegetative Index (NDVI) but has a significant effect on the Soil-Plant Analysis Development (SPAD). Yield and yield components were significantly influenced by crop rotation in this study as yield, plant height, cob weight and number of grains per row all recorded lower mean at $5 \%$ probability levels.
\end{abstract}

Keywords: Cropping system, maize, drought, yield and yield components.

\section{INRTODUCTION}

Maize (Zea mays L.) is a highly productive crop under optimal environmental and crop management conditions and is a major cereal crop worldwide, serving as a major staple for both human consumption and animal feed. It has also become a key resource for industrial applications and bioenergy production. It is a versatile crop and ranks third following wheat and rice in world production as reported by Food and Agriculture Organization (FAO 2002).

However, maize plants are also very susceptible to drought and heat; each year, an average of $15 \%$ to $20 \%$ of the potential world maize production is lost due to these stresses (Lobell et al. 2011)

Drought stress or water deficit is an inevitable and recurring feature of global Agriculture. Kramer (1980) reported that about one-third of the world's potentially arable land suffers due to water shortage, and most of the crops production is often reduced by drought.

Drought is a worldwide phenomenon and is a major production constrain, reducing crop yields. The extent of climate change over the next 20 years and it impact are difficult to predict but it is essential to put research in place now that will be needed in the long term (Parry et al. 2007).

The maize crops may experience reductions of grain yields when subjected to water deficit during the critical period of crop cycle from tasseling stage to initiation of grain filling.

Drought stress causes deceleration of cell enlargement and thus reduces stem length by inhibiting inter nodal elongation and also checks the tillering capacity of plants (Ashraf and Oleary 1996). Drought several studies have also shown that optimum yield can be obtained with irrigation at branching, flowering and pod formation stages (Priher and Sandhu 1968). In fact, well-regulated deficit irrigation regimes may increase crop yield compared to the crop grown under conditions of free from water deficit (Deng et al. 2002, Kang et al. 2002). The increased crop yield with regulated irrigation is mainly due to the systems allowing crop plants to grow under certain degrees of water stress at non-critical growth stages.

Maize monoculture and biculture are still present on large areas owing to the domination of maize in a general sowing structure. Crop rotation is a cropping system that has many advantages, reflected in better crop growth and yielding. The most widespread rotational practice is a two-crop rotation (winter wheat-maize), while three-crop rotation (winter wheat-maize-soybean) is the next most frequent. It is a known fact, that maize rotation with other crops can decrease the number of pathogens, pests and weeds, maintain or increase soil fertility, enabling better conditions for maize growth and development, so that higher yields can be expected as reported by; (Dolijanović et al. 2006, Stranger and Lauer 2008, Riedell et al. 2009).

\section{MATERIALS AND METHODS}

This research was carried out in the Látókép Research site of the University of Debrecen in the cropping year of 2017. The experimental site is located at Látókép Hajdúság ridge, about $15 \mathrm{~km}$ way from the city center of Debrecen and its geographical coordinates are $47^{\circ} 33^{\prime} \mathrm{N}, 21^{\circ} 27^{\prime} \mathrm{E}$.

The experimental soil is flat and leveled and the soil genetic properties belong to the calcareous chernozem. The experiment design was set up on a split-split-plot design in 4 replication. The research was carried out based on a two-factorial parameters and these are the nutrition levels (control, $80 \mathrm{~kg}$ of Nitrogen and $120 \mathrm{~kg}$ of Nitrogen), and different irrigation treatment (Full irrigation and non- irrigation) on a plot of land with plant density of $\left(72500 \mathrm{ha}^{-1}\right)$.

The factors that were considered in this study included, the morphological and physiological parameters were measured on the field at four different dates thus, $13^{\text {th }}$ June, $30^{\text {th }}$ June, $19^{\text {th }}$ July and $23^{\text {rd }}$ August in the cropping year 2017 (SPAD, LAI, NDVI) as well as yield and components thus, cob length, cob diameter, number of rows per cob, number 
of kernel per row, etc. The grain moisture and nutritional content were also measured at harvest.

The results of data for this study were processed and statistically evaluated using software Microsoft Excel and SPSS for windows.

The objective of this study was to investigate the influence of different cropping systems: monoculture and biculture (maize and wheat rotation) on the yield and yield components of maize (Zea mays L).

\section{RESULTS AND DISCUSSION}

In Table 1 I show the monthly precipitation between March and September 2017 and deviations from the 30-years average values in DebrecenLátókép.

In the end of the cropping season of 2017, the deviation in April, July and September was positive, thus the lack of precipitation in the other months was balanced and the total precipitation of the season was higher $379.9 \mathrm{~mm}$ than the 30-years average of 345.1 .

In the irrigation treatment, optimal water-supply of plants shall be reached by adapting irrigation water amounts to the local temperature and precipitation values of the cropping season (2017).

Results and analysis of data presented in this study shows a significant effect on SPAD as indicated in Table 2.

The monthly precipitation between March and September 2017 and deviations from the 30-years average values in Debrecen-Látókép

\begin{tabular}{|c|c|c|c|}
\hline & \multicolumn{2}{|c|}{2017} & \multirow{2}{*}{30 -years average $(\mathrm{mm})$} \\
\hline & Value $(\mathrm{mm})$ & Deviation $(\mathrm{mm})$ & \\
\hline March & 24.5 & -9.0 & 33.5 \\
\hline April & 50.4 & 8.0 & 42.4 \\
\hline May & 31.9 & -26.9 & 58.8 \\
\hline June & 62.3 & -17.2 & 79.5 \\
\hline July & 71.6 & 5.9 & 65.7 \\
\hline August & 47.5 & -13.2 & 60.7 \\
\hline September & 91.7 & 53.7 & 38.0 \\
\hline Total & 379.9 & 1.3 & 345.1 \\
\hline Average temperature $\left({ }^{\circ} \mathrm{C}\right)$ & 16.3 & 0.2 & 16.9 \\
\hline
\end{tabular}

Effects of cropping culture on photosynthetic and nutrition quality of maize

\begin{tabular}{llccccc}
\hline \multicolumn{1}{c}{ Treatments } & SPAD & NDVI & LAI & Protein & Starch & Moisture \\
\hline Monoculture & $50.986^{*}$ & 76.111 & 2.806 & 8.633 & 73.778 & 17.022 \\
Biculture & 54.878 & 77.444 & 2.333 & 8.878 & 74.078 \\
CV $(\%)$ & 0.036 & 0.393 & 0.052 & 0.589 & 0.489 & 0.484 \\
\hline
\end{tabular}

Note: * significant at $5 \%$ probability levels

Cropping system did not have a significant effect on the other photosynthetic and nutrition quality on the grains as shown below in Table 1 although they all recorded a high means on the biculture cropping system, but these high means did not show significant difference against the monoculture in this study. Plants react to stress in relation to their photosynthetic chlorophyll and carotene levels. Mayfield and Taylor (1984) underlined a connection between a decrease in light harvest of maize plants and lower carotenoid content. Some other studies such as Bónis et al. (2006), has reported positive effects of on cropping systems on chlorophyll synthesis, which may lead to an increase in maize yielding potential.

Results presented in Table 3 indicate a significant effect on the yield and yield components parameters except the number of rows per cob. The effect of cropping system on the yield of maize cannot be over emphasized. The yield-increasing effect of crop rotation on the maize yield was inversely proportional to the ratio of maize in the yield of maize in this study, depends on yield components and other plant characteristics, such as resistance to pests and tolerance to environmental stress factors and these findings coincide with (Kang 1998). The long-term use of crop rotation or the application of supplemental $\mathrm{C}$ sources such as farmyard manure or additional crop residues may increase soil aggregate stability, microbial and earthworm activity and soil water storage, and optimize the soil physical environment for crop growth (Karlen and Doran 1993). This could be an explanation for the rotation effect of the maizewheat biculture in this research.

Again, better yield explanation for cropping system treatment could be also considered through the allopathic properties of decomposing residues within the soil from the previous crop. This is found to be inhibitive for the soil microorganisms, pests and weed as reported by (Alsaadawi 2001), thus protecting nitrogen and other nutrients incorporated as a part of second crop residues from leaching or consumption by weed, and therefore providing nutrients for higher maize yields and yield components in the biculture treatment as shown in Table 3. 
Effects of cropping culture on yield and yield components of maize

\begin{tabular}{lccccccc}
\hline \multicolumn{1}{c}{ Treatments } & Plant height & Cob lenght & Cob weight & $\begin{array}{c}\text { No of grain/ } \\
\text { row }\end{array}$ & $\begin{array}{c}\text { No of rows/ } \\
\text { cob }\end{array}$ & $\begin{array}{c}\text { Grain weight/ } \\
\text { cob }\end{array}$ & Yield \\
\hline Monoculture & $232.511^{*}$ & 17.630 & $168.133^{*}$ & $35.370 *$ & 15.481 & 540.704 & $4041.042^{*}$ \\
Biculture & 251.022 & 19.022 & 221.122 & 40.889 & 15.556 & $191.137 *$ & 6178.877 \\
CV $(\%)$ & 0.003 & 0.17 & 0.019 & 0.022 & 0.886 & 0.000 & 0.002 \\
\hline
\end{tabular}

Note: * significant at $5 \%$ probability levels

Reductions in maize yields in a monoculture plot are mostly noticed after a dry winter, particularly if the summer is also dry. In a maize monoculture the yield loss could be attributed to the large number of barren plants, to the lower kernel number per plant and to the smaller thousand kernel mass and increased weed pressure could also be a contribution factor to yield losses. Riedell et al. (1998) also stated that the level of inputs provided for maize can affect the crop rotation response to yield.

\section{CONCLUSION}

Drought stress or water deficit is an inevitable and recurring feature of global agriculture a result of the changing effects of climate changes world over. However, adopting crop rotation, particularly if it is combined with best agronomic practices and the right timing would have a positive effect on the yielding potential by increasing LAI, chlorophyll and carotenoids contents. This experiment data shows that there is a strong influence of cropping system on yield and yield parameters in a non-irrigated field.

\section{REFERENCES}

Alsaadawi, I. S. (2001): Allelopathic influence of decom-posing wheat residues in agro ecosystems. J. Crop Prod. 4: 185-196.

Ashraf, M.-Oleary, J. W. (1996): Effect of drought stress on growth, water relations and gas exchange of two lines of sunflower differing in degree of salt tolerance. Int. J. Plant Sci. 157: 729732.

Bónis, P.-Árendás, T.-Marton, L. Cs.-Berzsenyi, Z. (2006): Herbicide tolerance of Martonvásár maize genotypes. Acta Agronomica Hungarica. 54: 517-520. Crop Science 191: 172184.

Deng, X.-Shan, L.-Shinobu, I. (2002): High efficient use of limited supplement water by dryland spring wheat. Trans. CSAE. 18: 84-91. (in Chinese)

Dolijanović, Ž.-Kovačević, D.-Oljača, S.-Broćić, Z.-Simić, M. (2006): The yield grain of winter wheat and maize in continuous cropping, two- and three-crop rotation. Journal of Scientific Agricultural Research. 67: 81-90.

FAO (2002): Fertilizer and the future. IFA/FAO Agriculture Conference on Global food security and the role of Sustainability Fertilization. Rome, Italy. 16-20 ${ }^{\text {th }}$ March, 2003. 1-2. Agroecosystem. J. Crop Prod. 4: 185-196.

Kang, M. S. (1998): Using genotype-by-environment interaction for crop cultivar development. Adv. Agron. 62: 199-252.

Kang, S.-Zhang, L.-Ling, Y.-Hu, X.-Cai, H.-Gu, B. (2002): Effects of limited irrigation on yield and water use efficiency of winter wheat in the Loess Plateau of China. Agric. Water Manage. 55: 203-216.
Karlen, D. L.-Doran, J. W. (1993): Agroecosystem Responses to Alternative Crop and Soil Management Systems in the U.S. Corn-Soybean Belt. International Crop Science I. Crop Science Society of America. Madison. 55-61.

Kramer. P. J. (1980): Drought stress and the origin of adaptation. [In: Turner and Kramer (eds.) Adaptation of Plants to Water and High Temperature Stress.] John Wiley and Sons. New York. USA

Mayfield, S. P.-Taylor, W. C. (1984): Carotenoid-deficient maize seedlings fail to accumulate light-harvesting chlorophyll $\mathrm{a} / \mathrm{b}$ binding protein (LHCP) mRNA. European Journal of Biochemistry. 144. 1: 79-84.

Prihar, S.S.-Sandhu, B. S. (1968): Irrigation of field crops, Indian Council of Agric. Res. New Delhi. 142.

Riedell, W. E.-Schumacher, T. E.-Clay, S. A.-Ellsbury, M. M.Pravecek, M.-Evenson, P. D. (1998): Corn and soil fertility responses to crop rotation with low, medium, or high inputs. Crop Sci. 38: 427-433.

Stranger, T. F.-Lauer, J. G. (2008): Corn grain yield response to crop rotation and nitrogen over 35 years. Agronomy Journal. 100. 3: 643-650.

Lobell, D. B.-Bänziger, M.-Magorokosho, C.-Vivek. B.(2011): Nonlinear heat effects on African maize as evidenced by historical yield trials. Nature Climate Change. 1: 42-45.

Parry, M. L.-Canziani, O.-Palutikof, J. P.-van der Linden, P. J.Hanson, C. E. (2007): Climate Change (2007) - Impacts, adaptation and vulnerability. Cambridge University Press. Cambridge. 